\title{
Discovery, acceptance and realization of Christian love as the foundation for engaged couples' formation
}

The family has its own naturally strong foundations that result from unique hard to be duplicated in a different life environment - bonds formed among its members; these bonds are essential to the mental, spiritual, but also physical ${ }^{1}$

* Prof. dr hab. Józef Stala - priest of Tarnów Diocese (Poland). Full Professor of Theology (Catechetics), Professor at the Pontifical University of John Paul II in Krakow (UPJPII), Vice Rector for the Scientific Capacity and International Cooperation UPJPII. Vice Dean for Research, Development and International Cooperation (2010-2014) and the Head of the Research Section of Pedagogical and Catechetical Studies at the Pontifical University of John Paul II in Krakow (UPJPII), Theology Faculty, Section in Tarnów (WTST). Lecturer in Catechetics and the Head of Pedagogical Practices at the same faculty. A member of the European Catechetical Equips; the European Society of Catholic Theology (ESCT); Section of Lecturers of Catechetics in Poland, Polish Familiology Association, Polish Theological Society and Tarnów Scientific Society. Expert (theology and family studies) of the Polish Accreditation Committee (PKA). Editor in chief of the international scientific journal "The Person and the Challenges". Expert of the Catholic Education Commission of Bishops' Conference of Poland in the matters of RE programme and catechetical textbooks evaluation. Participant and organizer of many catechetical and educational conferences, symposiums and congresses in Poland and abroad. He has published and edited widely in the field of catechetics and pedagogy, especially in family catechesis, family studies, religious education, upbringing and pastoral care. Co-author and editor of many RE textbooks.

1 Cf. A. Doboszyńska, Zagrożenia zdrowia i życia rodziny, in: $W$ trosce o rodzinę. W poszukiwaniu prawdy, dobra i piękna, red. M. Ryś, M. Jankowska, Warszawa 2007, pp. 269-270. 
health of its members. What constitutes the defining characteristics of the family is its natural character, the communal relationships it forms that help the family survive and overcome the hardships it encounters. The bonds between individual family members usually have a very personal character, are intimate and warm, and the solidarity that they inspire is selfless. As result of these close interactions among family members, separate individuals seem to merge into a community or even a unity. ${ }^{2}$

In its very essence, the family is a collection of interpersonal relations that connect people who form it - the community that is created through parenthood. The family and marriage are more than just institutions. When it comes to the family, personal relations are important since the family constitutes a special instance of entrusting one person to the other. In the family, a set of interpersonal relationships is formed. We can speak here of spousalness, fatherhood and motherhood, filiation and fraternity, through which each human person is introduced into the humankind and the family of God. The family is a primary unit of every human community that should constitute the foundation of every society. The need to interact and to open yourself to the other person can be met mainly in the family - the place where each person exists as an individual and unique being. Each meeting that takes place in the family environment should respect the subjectivity of each member of the family. ${ }^{3}$

2 Cf. Letter to families from Pope John Paul II Gratissimam Sane (henceforth Gratissimam Sane), 2, https://w2.vatican.va/content/john-paul-ii/en/letters/1994/documents/hf_jp-ii_let_02021994_families.html; A. Polnik-Klajn, Rozważania o rodzinie jako specyficznym środowisku wychowawczym oddziaływań interpersonalnych, in: Rodzina. Historia i współczesność. Studium monograficzne, red. W. Korzeniowska, U. Szuścik, Kraków 2006, p. 359; J. Rembowski, Z psychologicznych zagadnień życia w rodzinie, in: Rodzina i dziecko, red. M. Ziemska, Warszawa 1986, p. 127.

3 See: Apostolic exhortation Familiaris Consortio of Pope John Paul II on the role of the Christian family in the modern world (henceforth Familiaris Consortio or FC), 15, http:// w2.vatican.va/content/john-paul-ii/en/apost_exhortations/documents/hf_jp-ii_exh_19811122_ familiaris-consortio.html; J. Mastalski, Zarys teorii wychowania, Kraków 2002, pp. 197-204; P. Łastowska, Komunikacja międzypokoleniowa młodzieży z dorostymi. Aspekty pedagogiczno-katechetyczne, in: Troska Kościoła o współczesna polska młodzież. Zarys problematyki, red. A. Offmański, Szczecin 2008, p. 142; J. Stala, Personalistyczny charakter życia i wychowania rodzinnego, in: Dzisiejsze aspiracje katechezy rodzinnej. Problemy i wyzwania, red. J. Stala, E. Osewska, Kielce 2005, p. 375; J. Czarny, Jana Pawła II wizja cywilizacji miłości, Wrocław 1994, pp. 184-185. 
To fulfil the prerequisite of being a human, one needs to realize love and adopt a serving attitude towards the other person, which can be manifested through acts of affirmation addressed to them. The category of a selfless gift of yourself is of particular significance in a marriage covenant, as man and woman were created the way they are to be able - through their own dissimilarity - to give each other a specific gift of their own humanity. But to make it possible for a Christian married couple to give and receive each other, a continual development that entails the discovery, acceptance and realization of the principles of Christian love is necessary. It is of paramount importance today, at the beginning of the $21^{\text {st }}$ century, in the face of the consumption, technological and utilitarian attitude that weakens, destroys or even kills an appropriate relationship between people, to invoke the basic principles of love as formulated by Christianity. Without them, married love can easily be diminished to the categories of emotions, pleasure or use. Preparing an engaged couple for marriage and family life involves numerous aspects that are related to the nature of love, sacramental marriage and the family community founded on the sacrament of marriage. This article is going to explore the basic notions regarding love, as seen from the Christian perspective, that should be taken into account in the formation of engaged couples.

\section{God as the source of marital and family love}

People preparing for the sacrament of matrimony have their dreams, expectations and own notions about their future marriage. However, they are often based on what they have learned from movies and TV series. Some of affianced couples attach a great importance to the elements actively promoted by the media, such as: beauty, health, financial resources, good professional and social position. It is often the case that when it comes to marriage, in TV series it is a crush, an infatuation or the physical attractiveness of a person that plays the key role in the decision about marriage. Considering that, it often happens that love is equated with attractiveness and emotional involvement, which is the reason why when the intensity of feelings fades (which is a natural process), some people think that their love is over and they cannot be together anymore. This is the reason why a couple preparing 
for marriage should discover that love means much more than just video presentations, it is an act of will, the acceptance of the other person and continuous care of him/her. Love, as seen from that point of view, sets high requirements for the engaged couple, so some of them think that they are beyond human capabilities and require heroism. If we were to relate love only to the human capacity, it would be fragile and weakened, which is the reason why the Christian perspective is needed. The love experienced by an engaged or married couple goes beyond their mutual acceptance, but means an answer to the call of God who appointed man to realize love. Christians need to discover that their love stems from the love of God. He was the first to love man and gradually revealed His love and His plan of salvation to us.

God created man as an entity called to love that exists in Him - to love that He is Himself. ${ }^{4}$ God bonded human hearts with such a covenant that makes Himself be the love that unites human hearts. Therefore, the Christian spouses, participating in the love of Jesus Christ, are called to testify with their lives to the love that was revealed by God through his Incarnate Son. The internal logic and dynamics of love turn man and woman towards God who is love, as well as its source and end. Marital love is an extension of the love of God. This is a fundamental feature of Christian love. ${ }^{5}$ Only when human love becomes God's love, it will bear all things, endure all things, and will not insist on its own way. If the engaged and the married wish for their love to overcome all hardships, they need to turn to its source - to the love of God.

Marital love particularly reveals its true nature and nobility when it takes its origin from the supreme source, from God who is love. God, who created man in His own image and likeness, calling him to existence through love, called him at the same time to the realization of love. Love is therefore the fundamental and intrinsic vocation of every human being. ${ }^{6}$ For that reason,

4 See: FC 11.

5 Cf. M. Czachorowski, Ku epoce rodziny, Łomianki 2000, pp. 62-63.

6 See: Humane Vitae (HV) 9; Redemptor Hominis (RH) 10; Familiaris Consortio (FC) 11; Chatechism of the Catholic Church 372-373; K. Wojtyła, Miłość i odpowiedzialność, Lublin 1982 (English version: Love and responsibility, transl. H. T. Willetts, London-New York 1981); J. Laskowski, Małżeństwo wspólnota miłości, Warszawa 1993; W. Bołoz, Promocja osoby w rodzinie, Warszawa 1998, pp. 50-55; J. Wilk, Pedagogika rodziny. Zagadnienia wybrane, Lublin 2002, pp. 140-145; H. Krzysteczko, Pomoc $w$ dojrzewaniu do miłości, małżeństwa i rodziny. Studium teologiczno-pastoralne, Katowice 2000, p. 49; F. Adamski, Rodzina. Wymiar społeczno-kulturowy, Kraków 2002, p. 201. 
the most important commandment of the New Testament is that of love, understood also as love between a man and a woman, which is meant to lead, by its very nature, to common marital and family life.

\section{The fullness of marital love}

According to the Christian interpretation, the ideal of marital love is embodied in the love of Jesus Christ to the Church, which is why the love between all Christian married couples is always closely related to the love between Christ and the Church. For Christians called to marriage, the sacrament of matrimony is at the same time a vocation and a commandment, which implies that they must remain faithful to each other forever, beyond every trial and difficulty, in generous obedience to the holy will of the Lord. The communion between God and His people finds its definitive fulfilment in Jesus Christ, the Bridegroom who loves humankind and gives Himself to it as the Saviour, uniting it in His body. It is Him who reveals the original truth of marriage, the truth of the beginning, and freeing man from hardness of his heart, makes them capable of realizing this truth in its entirety. This revelation reaches its definitive fullness in the gift of love which the Word of God gives to humankind, in assuming the human nature and in the sacrifice which Jesus Christ makes of Himself on the Cross for His bride, the Church. The intention which God has imprinted in the humanity of man and woman since their creation is entirely revealed in this sacrifice. Therefore, conjugal love reaches its fullness when the spouses - through their caritas - participate in and are called to live the love of Christ who gives Himself on the Cross. ${ }^{7}$ The family community has its roots in the natural complementarity of man and woman, which is purified and enriched in the sacramental gift of Jesus Christ. ${ }^{8}$

7 See: HV 25; FC 15-17; Sacred Congregation for the Doctrine of the Faith, Persona Humana. Declaration on certain questions concerning sexual ethics (henceforth Persona Humana), 3-4, http:/www.vatican.va/roman_curia/congregations/cfaith/documents/rc con_cfaith_doc_19751229_persona-humana_en.html; F. Adamski, Rodzina..., pp. 105-108; F. Adamski, Edukacja, rodzina, kultura. Studia z pedagogiki społecznej, Kraków 1999, pp. 5964; W. Bołoz, Promocja osoby..., pp. 243-244; H. Krzysteczko, Pomoc w dojrzewaniu..., pp. 50 53; D. Opozda, Integracja rodziny a wiedza o małżeństwie u młodzieży, Lublin 2001, pp. 16-21.

8 Cf. FC 19. 
The marital communion of love must be characterized not only by its unity, but also by its indissolubility as well as total and mutual fidelity of the spouses. Conjugal love has its foundation in Jesus Christ. ${ }^{9}$ Marriage is a symbol of the union between Jesus Christ and the Church that was made at the cost of His blood. This love is the foundation of the unity and indissolubility of marriage because if it were temporary, it could not be the symbol of the relationship between Jesus Christ and the Church. This is the reason why Christian marriage is indissoluble and has to last until either of the spouses dies. ${ }^{10}$ Marital love of Christians is not a passing fancy that stems from a selfish pursuit of happiness, but implies the requirement of lifelong fidelity to the spouse. For this reason, when it comes to the preparation of an engaged couple for marriage, we need to remind them about its unity and indissolubility that are directly implied by its sacramental character.

\section{Love as acceptance of the other person and a gift of yourself}

Love, in its deepest sense, allows man to see the other person and the good in them, and to leave their own selfishness behind. It is of particular importance in a relationship with the other person. In this sensitive aspect of human life, there is a danger of objectifying the other person. Through an act of love, we discover the other person, who so far has not been singled out in the world full of other people, as the only one, recognized and chosen. ${ }^{11}$ Conjugal love is affirmation of the other person in all their dimensions physical, mental and spiritual. Hence, the need to teach every man how to attain integration and a mature personality. Full affirmation of the other person must come from appreciation of the personal character of wife or husband. In this context, the preparation for marriage and family life should

9 Cf. FC 20; GS 48.

10 Cf. Ef 5: 32; FC 19; Gratissimam Sane, 8; C. Murawski, Teologia małżeństwa i rodziny w nauczaniu biskupów polskich 1945-1980, Sandomierz 1988, p. 57.

11 Cf. FC 22; K. Wrońska, Karola Wojtyły personalistyczna filozofia wychowania, in: Wychowanie na rozdrożu, red. F. Adamski, Kraków 1999, p. 192; J. Majka, Wychowanie personalistyczne - wychowaniem integralnym, in: Człowiek - wychowanie - kultura, red. F. Adamski, Kraków 1993, p. 98. 
perfect the ability to forget one's selfishness and be open to the other person, appreciating their value.

Man is called to love in the unity of their body and spirit. Femininity and masculinity are complementary gifts, therefore human sexuality plays the role of integrating this ability to love. To accept your spouse means to accept their sexuality. Sexuality is a fundamental component of personality, one of its modes of being, manifestation, communicating with others, feeling, expressing and living human love. Therefore, "sexuality [...] is by no means something purely biological but concerns the innermost being of the human person as such. It is realized in a truly human way only if it is an integral part of love by which a man and a woman commit themselves totally to one another until death. The total physical self-giving would be a lie if it were not the sign and fruit of a total personal self-giving." ${ }^{2}$

Affirmative marital love leads to a marriage dialogue ${ }^{13}$ that is held on three levels: between the spouses who do not "use" each other as "objects" but respect their "human sexuality," also in its physical dimension, which is manifested in "responsibility" and "living a personal love."14 It is also held between parents and children, as a result of which a unique educational exchange between them takes place, in which parents affirm their children, and children affirm their parents. As a consequence, each party gives and receives, so it is not only children who are on the receiving end of this relationship, but also parents. ${ }^{15}$ The third level describes the relationship between a family and other families, and between the Church and the world. While affirming its own members, the family community is also open to other people. Especially in the face of society that is running the risk of becoming more and more depersonalized and standardized, the family emphasises the value of every human being. ${ }^{16}$ The family is called to be open to the social environment and to help their neighbours to protect their rights and duties, having in mind the care for other people as well as the sense of justice and responsibility.

12 FC 11.

13 Cf. Decree on the apostolate of the laity Apostolicam Actuositatem, 11, http://www. vatican.va/archive/hist_councils/ii_vatican_council/documents/vat-ii_decree_19651118_ apostolicam-actuositatem_en.html; GS 52; Gratissimam Sane 2-3; FC 42-43.

14 Cf. FC 32.

15 Cf. FC 21

16 Cf. FC 43. 
Acceptance and affirmation of the other person in the family needs to be complemented with the gift of love. Since it is self-giving that should invigorate the mutual love between the spouses and refer to all kinds of everyday situations, the category of a gift distinguishes love from its semblance. The spouses, maintaining their dignity, bestow on each other all their abundance. "This mutual gift of the person in marriage opens to the gift of a new life. [...] The gift of interior readiness to accept the child and bring it into the world is linked to the marriage union, which should constitute a special moment in the mutual self-giving both by the woman and the man." ${ }^{17}$ Man and woman are a gift for each other when each of them exists together with and totally for somebody. The nature of the marital community cannot be comprehended without the category of a "sincere gift of oneself" through which a person develops. Man and woman are complementary, which means that they are able to complement each other on the physical, mental and personal level: masculinity is confirmed through femininity and femininity finds itself in the presence of masculinity.

\section{Fulfilling the commandment of love on everyday basis}

Love between husband and wife, and between family members, based on a proper hierarchy of values, can be perfected through the everyday realities that concern and distinguish their state of life. ${ }^{18}$ Taking advantage of these opportunities and progressing towards an ever richer union with each other on every level - the level of the body, heart and will, the spouses reveal their love to the Church and to the world. Man is not a purely spiritual entity, so the spiritual dimension needs to be manifested also on a bodily level through a word, smile, look, gesture, and sexual intercourse. Through all daily words and gestures of love, the spouses follow the guidance of the Gospel in the life of the family community. Sharing love takes place in every moment of family life, both in times of joy and happiness, and in times of sorrow, weakness and crisis. Everyday love manifests itself both in ordinary care for the fulfilment of basic needs of family members, in bringing up children, up to heroic gestures

17 Pope John Paul II speaks on women, ed. B. W. Deely, Washington 2014, p. 154.

18 Cf. FC 50. 
of love, such as taking care of the needy, following the example of the Master of Nazareth. Thanks to the community character of family life, it can serve those in need, take care of the sick and suffering. ${ }^{19}$

The family is strong enough to help its members find a place, in which they can find their own identity. At the same time, each member of the family has to show care not only for their own life but also for the life of other members. The family is characterised by the direct character of interpersonal relations, simplicity and concreteness, intimacy and affection, while love expressed on a daily basis helps one man open up to the other, and to God. Conjugal and family love is revitalized and sustained by an unceasing inner dynamism, by the daily experience and care, manifested through its indissolubility, the spirit of sacrifice, pardon and reconciliation. ${ }^{20}$ The family needs a dynamism of love that will allow for the development of each of its members, for the sake of their dignity as a person, through fostering their dignity and vocation. As a community of persons, the family - participating in the most natural way in everyday life of almost each person and knowing their needs and problems becomes a real symbol of love. ${ }^{21}$

The formation of people in accordance with the laws of free giving, respect, encounter and dialogue, and solidarity lets the family community undertake and complete the task of upbringing. ${ }^{22}$ Therefore, only parents who love each other can guarantee a harmonious and integral development of a child. ${ }^{23}$ The child is, as it were, introduced to the mystery of God through the daily intimacy of their parents and family. ${ }^{24}$ It is them who through the relation of

19 Cf. FC 71.

20 Cf. FC 21; Persona Humana 7; J. Mastalski, Zarys teorii wychowania, Kraków 2002, p. 198.

21 Cf. FC 20-27; G. Hibon, Zaangażowanie małżénskie, in: XVIII Międzynarodowy Kongres Rodziny, Warszawa 1994, p. 441; M. Szachta, Cel: człowieczeństwo - dialog - miłość, "Edukacja i Dialog” 2002 nr 2, p. 62; T. Gadacz, Wychowanie jako spotkanie osób, in: Wprowadzenie do pedagogiki ogólnej. Zagadnienia wybrane, red. J. Kostkiewicz, Stalowa Wola 1999, p. 195; T. Bilicki, Dziecko i wychowanie w pedagogii Jana Pawła II, Kraków 2000, p. 68.

22 Cf. FC 43.

23 Cf. M. Szachta, Cel: człowieczeństwo..., p. 62; T. Gadacz, Wychowanie jako spotkanie..., p. 195; T. Bilicki, Dziecko i wychowanie..., p. 68.

24 Cf. P. Semik, Miejsce katechezy rodzinnej w procesie religijno-moralnego wychowania dziecka, "Seminare" 1981, pp. 111-124; J. Tarnowski, Katecheza w rodzinie: obawy i nadzieje, "Katecheta” 25 (1981) nr 6, pp. 255-258; J. Tarnowski, Spotkać Boga w rodzinie, "Katecheta" 26 (1982) nr 1, pp. 101-110; J. Pate, Welcome. Celebrations with young children for the Church's 
selfless love direct their child to God. The family is not only a legal, social and economic unit but a natural community of love. Each person is affirmed in it as a subject of love. The family, after all, is founded on love and takes the roots from it, since love is its greatest power, the internal principle, without which it can neither grow nor perfect itself. ${ }^{25}$ However, love that man experiences in the family assumes full acceptance of an individual, along with all their talents and limitations, and mutual support of family members in their personal development. A correct relationship between a parent and a child should involve the following aspects: love, acceptance, respect for the child, expressed through respect for their feelings and needs, acceptance of their problems and limitations, noticing their efforts and strengths, trusting them and devoting time and attention to them. However, these efforts should be complemented with boundaries, norms and expectations to be set for the child. ${ }^{26}$

Every day, family members offer their generous service in their own individual way, following the example of the sacrificial love of Jesus Christ. In the contemporary society, where the concept of service is often understood as something negative, there is a dire need to propagate the truth about the ministerial character of true human love. Without the self-giving attitude, generosity and service, it is difficult to imagine a true and lasting marital bond. A proper attitude of the spouses, involving daily selfless service, becomes the most reliable test of their personal bond.

year, London 1989; J. Pate, Easter plus. Family activities from Lent to Pentecost, London 1991; The Pastoral Formation Team, Moments that matters. Preparing for the sacrament of Eucharist, Chelmsford 1995; The Pastoral Formation Team, Moments that matters. Preparing for the sacrament of reconciliation, Chelmsford 1995; Ch. Brusselmans, A Parents' guide: religion for little children, Huntington 1970; Ch. Brusselmans, H. Haggerty, We celebrate Eucharist, Morristown 1975.

25 RH 10; FC 18; Gratissimam Sane 7-8; J. Bajda, Powołanie małżeństwa i rodziny, in: Teologia małżeństwa i rodziny, red. K. Majdański, Warszawa 1980, p. 103; J. Bajda, Etos rodziny fundamentem społeczeństwa, "Z Pomocą Rodzinie" 1990 nr 5, pp. 12-23; P. Wielgus, Rodzina wobec współczesnych zagrożeń, in: Rodzina. Źródło życia i miłości, red. D. Kornas-Biela, Lublin 2001, p. 15.

26 Cf. J. Wilk, Pedagogika rodziny...; J. Kułaczkowski, Pedagogika rodziny. Teorie wychowania w rodzinie, Warszawa-Łomianki 2009; V. Satir, Rodzina. Tu powstaje człowiek, Gdańsk 2000; P. Chrobak, Koncepcja wychowania personalistycznego w nauczaniu Karola Wojtyly Jana Pawła II, Warszawa 1999, pp. 91-92; J. Sakowska, Szkoła dla rodziców i wychowawców, Warszawa 1999. 
In the postmodern society, it is more and more difficult to prepare an engaged couple to marriage and family life. The examples given by the media, which have a great influence on the young generation, differ from the Christian vision of love. Therefore, it is necessary to introduce the concepts of acceptance and gradual realization of love, as seen by Christianity, to the formation of engaged couples. The affianced need to discover that their love is rooted in the love of God, and grows stronger because of it. They also need to see and accept the fact that their sacramental marriage is the sign of love of Jesus Christ to the Church. That is why conjugal love involves a total acceptance of the spouse in the physical, mental and spiritual dimension. Accepting these fundamental principles of understanding love as perceived by Christianity entails specific consequences. First of all, it means everyday realization of the commandment of love through a word, look, gesture, action and work. Conjugal and family love needs to be constantly enlivened, strengthened and nourished to become stronger and more dynamic. Young people are perfectly aware of the fact that in order to find a job in the future, or to take up a position in society, proper preparation is needed. It would be good if they also discovered the necessity to prepare well for life in a sacramental marriage and were offered appropriate assistance while being formed for love, marriage and family.

\section{Bibliography}

Adamski F., Edukacja, rodzina, kultura. Studia z pedagogiki społecznej, Kraków 1999.

Adamski F., Rodzina. Wymiar społeczno-kulturowy, Kraków 2002.

Bajda J., Etos rodziny fundamentem społeczeństwa, "Z Pomocą Rodzinie" 1990 nr 5, pp. 12-23.

Bilicki T., Dziecko i wychowanie w pedagogii Jana Pawła II, Kraków 2000.

Bołoz W., Promocja osoby w rodzinie, Warszawa 1998.

Brusselmans Ch., A parents' guide: religion for little children, Huntington 1970.

Brusselmans Ch., Haggerty H., We celebrate Eucharist, Morristown 1975.

Chrobak S., Koncepcja wychowania personalistycznego w nauczaniu Karola Wojtyly - Jana Pawła II, Warszawa 1999.

Czachorowski M., Ku epoce rodziny, Łomianki 2000. 
Czarny J., Jana Pawła II wizja cywilizacji miłości, Wrocław 1994.

Człowiek - wychowanie - kultura, red. F. Adamski, Kraków 1993.

Dzisiejsze aspiracje katechezy rodzinnej. Problemy i wyzwania, red. J. Stala, E. Osewska, Kielce 2005.

Krzysteczko H., Pomoc w dojrzewaniu do miłości, małżeństwa i rodziny. Studium teologiczno-pastoralne, Katowice 2000.

Kułaczkowski J., Pedagogika rodziny. Teorie wychowania $w$ rodzinie, WarszawaŁomianki 2009.

Laskowski J., Małżeństwo wspólnota miłości, Warszawa 1993.

Mastalski J., Zarys teorii wychowania, Kraków 2002.

Opozda D., Integracja rodziny a wiedza o małżeństwie u młodzieży, Lublin 2001.

Pate J., Easter plus. Family activities from Lent to Pentecost, London 1991.

Pate J., Welcome. Celebrations with young children for the Church's year, London 1989.

Religious education/catechesis in the family. A European perspective, red. E. Osewska, J. Stala, Warszawa 2010.

Pope John Paul II speaks on women, ed. B. W. Deely, Washington 2014.

Rodzina i dziecko, red. M. Ziemska, Warszawa 1986.

Rodzina. Historia i współczesność. Studium monograficzne, red. W. Korzeniowska, U. Szuścik, Kraków 2006.

Rodzina. Źródło życia i miłości, red. D. Kornas-Biela, Lublin 2001.

Sakowska J., Szkoła dla rodziców i wychowawców, Warszawa 1999.

Satir V., Rodzina. Tu powstaje człowiek, Gdańsk 2000.

Semik S., Miejsce katechezy rodzinnej w procesie religijno-moralnego wychowania dziecka, "Seminare" 1981, pp. 111-124.

Stala J., Der Mensch als Person: Die bestimmende Grundlage für Johannes Paul II. in seinem Bild von der Familie, "The Person and the Challenges" 2 (2012) No. 2, pp. 41-59.

Stala J., Lehrpläne und Schulbücher für den Religionsunterricht an den Staatlichen Grundschülen in Polen, "Bogoslovni vestnik" 70 (2010) nr 3, pp. 405-414.

Stala J., Osewska E., Anders erziehen in Polen. Der Erziehungs-und Bildungsbegriff im Kontext eines sich ständig verändernden Europas des XXI. Jahrhunderts, Tarnów 2009.

Stala J., Towards religious education in the family in the 21st century, in: The contemporary family: local and European perspectives, red. E. Osewska, J. Stala, Kraków 2015, pp. 309-318. 
Tarnowski J., Katecheza w rodzinie: obawy i nadzieje, "Katecheta" 25 (1981) nr 6, pp. $255-258$.

Tarnowski J., Spotkać Boga w rodzinie, "Katecheta” 26 (1982) nr 1, pp. 101-110.

Teologia małżeństwa i rodziny, red. K. Majdański, Warszawa 1980.

The pastoral formation team, moments that matters. Preparing for the sacrament of Eucharist, Chelmsford 1995.

Troska Kościoła o wspótczesna polska młodzież. Zarys problematyki, red. A. Offmański, Szczecin 2008.

W trosce o rodzinę. W poszukiwaniu prawdy, dobra i piękna, red. M. Ryś, M. Jankowska, Warszawa 2007.

Wilk J., Pedagogika rodziny. Zagadnienia wybrane, Lublin 2002.

Wojtyła K., Miłość i odpowiedzialność, Lublin 1982 (English version: Love and responsibility, transl. H. T. Willetts, London-New York 1981).

Wprowadzenie do pedagogiki ogólnej. Zagadnienia wybrane, red. J. Kostkiewicz, Stalowa Wola 1999.

Wychowanie na rozdrożu, red. F. Adamski, Kraków 1999.

XVIII Międzynarodowy Kongres Rodziny, Warszawa 1994. 